\title{
QUALITY OF LIFE IN ADULTS WITH INTELLECTUAL DISABILITIES - OBJECTIVE INDICATORS
}

\author{
Svetlana KALJAČA ${ }^{2 *}$ \\ Bojan DUČIĆ* \\ Sara ĐORĐIC** \\ *University of Belgrade \\ Faculty of Special Education and Rehabilitation \\ ${ }^{* *}$ Primary school "Sava Jovanović Sirogojno", Belgrade
}

The aims of this research were to determine the level of objective Quality of Life (QoL) in adults with intellectual disabilities (ID), the difference in QoL with regard to the participants' gender, as well as the relation among the examined life domains included in the applied QoL concept.

The sample included 39 adults with mild and moderate ID aged between 22 and $50(M=34.69, S D=7.49)$, and 40 typically developing (TD) participants between 19 and 60 years of age $(M=35.25, S D=12.21)$.

Seven domains of Comprehensive Quality of Life Scale - ID: Material well-being, Health, Productivity, Intimacy, Safety, Place in community and Emotional well-being were used to assess QoL level. These domains represent the indicators of objective QoL.

Participants with ID had significantly lower QoL than TD participants in the total score $(p=0.000)$ and in Health $(p=0.000)$, Productivity $(p=0.000)$ and Intimacy $(p=0.008)$ domains. When

1 This paper is the result of the research project "Creating a protocol for assessing educational potentials of children with disabilities, as a criterion for the development of individual educational programs", ON 179025 (2011-2015), financed by the Ministry of Education, Science and Technological Development of the Republic of Serbia

2 E-mail: kaljaca@eunet.rs 
Specijalna edukacija i rehabilitacija (Beograd), Vol. 17, br. 3. 305-334, 2018.

compared to male participants with ID, TD men had a higher total score $(p=0.001)$, and better results in Health $(p=0.021)$ and Productivity $(p=0.000)$ domains. This result was also confirmed in female participants with the addition of TD women being significantly more successful in Intimacy $(p=0.027)$ domain compared to women with ID. Statistically significant correlations among seven domains of QoL objective indictors in persons with ID were positive, ranging from moderate to high.

The obtained results indicate the domains which require more intensive support so that people with ID could have the opportunity to achieve QoL which meets the standards of the community they belong to.

Key words: Quality of Life, intellectual disabilities, support services, health, productivity, intimacy

\section{INTRODUCTION}

The questions regarding the development of the Quality of Life (QoL) holistic concept, its influence on personal well-being of people with intellectual disabilities (ID), and community support systems have significantly been dealt with over the last two decades. However, real implications of this concept on the lives of people with ID are still a matter of debate. Special attention has been given to three important questions which are closely related not only to the QoL concept, but also to immediate social environment: the problem related to providing different forms of needed support to persons with ID in accordance with economic capacities of the community, significant improvement of the self-advocacy movement of these people, and analysis of existing support services in order to precisely determine which activities truly affect personal wellbeing of people with ID. The importance of the development and implementation of QoL concept is reflected in the need for reform of attitudes towards people with disability to be based on this concept, with positive implications of implementing QoL concept in social inclusion and personal well-being of these people being the priority (Buntinx \& Schalock, 2010; Schalock, 2004; Schalock et al., 2005). 
QoL is a multidimensional concept whose definition cannot be considered satisfactory regardless of its significance and researchers' continuous efforts. Literature review shows that many authors define the quality of life concept with regard to the description of domains and indicators included in the concept, thus avoiding a precise definition or reliance on existing definitions, such as the one provided by the World Health Organization (WHO) (Barcaccia et al., 2013). According to $\mathrm{WHO}$, quality of life is a multidimensional construct which includes individuals' self-perception of the achievement level of personal goals, expectations and standards, as well as difficulties faced during that process. The quality and outcomes of this self-assessment are significantly related to a person's position within a cultural discourse and system of values he/ she lives in (The WHOQOL Group, 1995). The QoL construct integrates universal (etic) properties on one hand, and on the other specific cultural-bound (emic) properties which depend on personal beliefs, expectations, and social policies (Jenaro et al., 2005; Schalock et al., 2005).

The attitudes regarding different parameters and researchers' approaches to measuring QoL are not unanimous. According to Scandinavian experts on social indicators, subjective quality of life indicators mainly reflect what people want and expect, as well as the level of their adaptation to current conditions, and do not represent real life conditions (Ilić, Milić \& Aranđelović, 2010). This implies that priority should be given to objective indicators when measuring QoL. Contrary to this concept and the one of WHO, which promotes the importance of QoL subjective domain (The WHOQOL Group, 1995), the attitude according to which equal significance is given to both subjective and objective indicators has been present over the last few decades (Cummins, McCabe, Romeo, Reid \& Waters, 1997; Ruta, Camfield \& Donaldson, 2007; Schalock et al., 2002). Cummins (1998) states that it is important to respect the two-dimensional character of QoL concept, since objective parameters refer to generally accepted standards in the social discourse of a person's life, while 
subjective parameters refer to the level of personal satisfaction in different domains (material well-being, emotional wellbeing, health, productivity, intimacy, safety, and community life) measured by their significance for that very person.

The significance of including both objective and subjective parameters in determining QoL in persons with disability is particularly emphasized due to "the disability paradox" which denotes the phenomenon that people with disability perceive their quality of life as excellent or very good (Albrecht \& Devlieger, 1999; van Asselt-Goverts, Embregts \& Hendriks, 2015). However, it seems that the disability paradox is in significant correlation with contextual factors. Adverse social environment leads to limitations in performing life activities and social participation in some people with disability, while not in others, with the level of personal QoL perception of these people decreasing only if these limitations are present (Fellinghauer, Reinhardt, Stucki \& Bickenbach, 2012). Similar conclusions have also been reported before and are based on examining the attitudes of staff working with people with ID in residential institutions and day-care centers (Nota, Soresi \& Perry, 2006). These authors indicate the presence of a positive relation between personal satisfaction with social participation and the quality of support people with ID have on one hand and the values of objective indicators of their social well-being on the other. Although subjective satisfaction, as an individual's quality of life exponent, should not be neglected, it is necessary to interpret the obtained scores with regard to standards characteristic of social and cultural context of the community they live in. It seems necessary to be cautious, since the obtained results sometimes indicate individual improvement although this improvement is not always equivalent to the objective QoL improvement in persons with ID compared to other groups of people living in the same community (Townsend-White, Pham \& Vassos, 2012). Most researchers agree that it would be unethical to exclude persons with ID from the process of their QoL evaluation, but that it is also necessary to continue searching for more appropriate methodology which would 
enable obtaining more reliable information about subjective experiences of people with ID (Ruddick, 2005; TownsendWhite et al., 2012).

Results of studies on QoL in people with ID are not completely consistent. According to some available studies, the overall QoL of these people is lower than that of typically developing (TD) population (Hensel, 2000; Sheppard-Jones, 2003; Simões \& Santos, 2016; Wilson, Wiersma \& Rubin, 2016), while other findings confirm this tendency only in certain assessed QoL domains: health, productivity, community and emotion well-being (Hensel, Rose, Stenfert Kroese \& BanksSmith, 2002), self-determination, rights, social inclusion, personal development, interpersonal relationships, material well-being, physical wellbeing (Ribeiro et al., 2017), material well-being, health, productivity and community (Verri et al., 1999). It could be said that the results of most studies on QoL in people with developmental disabilities indicate poorer QoL in these people compared to control groups without disabilities in all four domains (physical functioning; emotional functioning; social functioning; school functioning). However, due to very heterogeneous results, there is still no clear profile with regard to QoL domain profiles that would be specific for a particular clinical group of people with disabilities (Jonsson et al., 2016).

The following factors are believed to have a significant influence on QoL in people with ID: medical conditions, type of housing, intensity of support (Lucas-Carrasco \& SalvadorCarulla, 2012; Petry, Maesa \& Vlaskamp, 2009), safety, general well-being (Chou et al., 2007), employment and material security (Wong, Wong, Schalock \& Chou, 2011), social welfare of parents, emotional well-being of people with ID, as well as the presence of changes in these domains (Cramm \& Nieboer, 2012), living conditions, diagnosis, age, development of social skills (Nota, Ferrari, Soresi \& Wehmeyer, 2007; Simões \& Santos, 2016) participants' gender (Julius, Wolfson \& Yalon-Chamovitz, 2003; Sheppard-Jones, 2003; Simões \& Santos, 2016), satisfaction with social contacts (van Asselt-Goverts et al., 2015) and presence of syndrome specificity (Wilson et al., 2016). 
Specijalna edukacija i rehabilitacija (Beograd), Vol. 17, br. 3. 305-334, 2018.

The main aim of this research was to determine quality of life in adults with ID measured by objective indicators. Secondary objectives were to determine the differences in QoL between the participants of different genders (total score and QoL domains), as well as to determine the significance of correlations among different life domains included in the QoL concept applied in this research.

METHOD

Sample

The research included 39 adults with mild and moderate ID aged between 22 and $50(\mathrm{M}=34.69, \mathrm{SD}=7.49)$, and 40 TD participants between 19 and 60 years of age $(M=35.25$, $\mathrm{SD}=12.21$ ). Preliminary analyses did not determine any statistically significant differences between participants with ID and TD participants with regard to gender $\left(\chi^{2}(1, n=78)=0.00\right.$; $\mathrm{p}=0.995)$ or age $(\mathrm{t}(64,97)=-0.245, \mathrm{p}=0.807)$. Table 1 shows a detailed description of age and gender structure of the sample. Participants with ID included in this research were users of day-care services for people with mental disabilities, while TD participants were secondary school students and employees in educational institutions.

Table 1 - Sample structure with regard to gender and age

\begin{tabular}{|c|c|c|c|c|c|c|}
\hline & \multirow{2}{*}{ gender } & \multirow{2}{*}{$\mathrm{N}$} & \multicolumn{4}{|c|}{ Age } \\
\hline & & & Min & Max & $M$ & SD \\
\hline \multirow{3}{*}{ Participants with ID* } & male & 18 & 23 & 50 & 34.50 & 7.99 \\
\hline & female & 20 & 22 & 45 & 35.10 & 7.33 \\
\hline & $\Sigma$ & 39 & 22 & 50 & 34.69 & 7.49 \\
\hline \multirow{3}{*}{ TD participants } & male & 20 & 19 & 60 & 33.05 & 12.64 \\
\hline & female & 20 & 19 & 54 & 37.45 & 11.66 \\
\hline & $\Sigma$ & 40 & 19 & 60 & 35.25 & 12.21 \\
\hline
\end{tabular}

* there is no information on gender for one participant with ID;

ID - intellectual disability; TD - typical development 


\section{Instruments and procedure}

Twenty-one items of Comprehensive Quality of Life Scale, Intellectual Disability, 5th Edition (Cummins, 1997) were used for quality of life evaluation based on objective indicators. The scale is aimed at adults with ID and other cognitive impairments, and it includes seven quality of life domains: Material well-being, Health, Productivity, Intimacy, Safety, Place in community and Emotional well-being. Answers are given on a five-point Likert scale. Each domain is represented by three items/indicators within the Scale. The results for each of the seven domains are obtained by adding up three corresponding raw scores, and the total score of objective QoL is the sum of the results of seven domains.

Internal consistency, obtained by applying a part of the Questionnaire that evaluates quality of life on the basis of objective criteria, was acceptable (Cho \& Kim, 2015) according to the instrument authors ( $\alpha=0.47)$ (Cummins, 1997), as well as Cronbach's alpha obtained on the sample in this research $(\alpha=0.621)$.

In accordance with the recommendation made by the author of the instrument used to measure objective QoL in this research (Cummins, 2001), that informants can also be proxies who know the person with ID well, information about objective QoL of people with ID in this study was obtained from special educators who provide support in day-care centers. The criterion for engagement in the research was that special educators worked with the person with ID for whom they provided information for at least a year, and that they were familiar with various aspects of that person's daily functioning. Such methodological approach is considered appropriate bearing in mind findings of other authors which indicate a high level of compatibility in the results obtained by selfreport procedures of people with ID and the scores obtained from proxies' reports (Perry \& Felce, 2002). TD participants provided information about objective quality of life indicators 
Specijalna edukacija i rehabilitacija (Beograd), Vol. 17, br. 3. 305-334, 2018.

by self-report technique. All participants participated in the research voluntarily. They were guaranteed anonymity and use of data solely for scientific purposes.

\section{Statistical data analysis}

Apart from descriptive statistics techniques used to show central tendency measures and results variability, $\mathrm{T}$ test was used to determine the differences with regard to gender, while Pearson correlation coefficient determined the significance and level of correlations of dependent variables.

Multivariate analysis of variance (MANOVA) was used to compare QoL scores of participants with ID and TD participants.

\section{RESULTS}

After preliminary evaluations of the assumptions about normal distribution of the results (Garson, 2012) (Table 2), linearity of pairs of dependent variables, univariate and multivariate atypical points (Pallant, 2013), homogeneity of variance matrices, covariance and multicollinearity, MANOVA was used to determine the relation between the level of participants with ID and TD participants on QoL total score and seven domains of objective QoL.

Table 2 - Results distribution on the complete sample

\begin{tabular}{lcc}
\hline & Skewness & Kurtosis \\
\hline Material well-being & -0.261 & -0.267 \\
\hline Health & -0.834 & 0.106 \\
\hline Productivity & 0.042 & -1.065 \\
\hline Intimacy & -0.582 & 0.092 \\
\hline Safety & -0.093 & -0.339 \\
\hline Place in community & 0.187 & -0.445 \\
\hline Emotional well-being & 0.004 & 0.159 \\
\hline QoL total score & -0.090 & -0.583
\end{tabular}

QoL - Quality of Life 
A statistically significant difference was determined between participants with ID and TD participants with regard to the combination of dependent variables (Wilks' $\lambda=0.29, F(7$, $71)=24.95, \mathrm{p}=0.000$, partial $\left.\eta^{2}=0.71\right)$. Significant differences were determined in Health, Productivity, Intimacy domains and QoL total score (Table 3).

Table 3 - Relation between QoL of persons with ID and TD persons

\begin{tabular}{|c|c|c|c|c|c|c|c|c|}
\hline $\begin{array}{l}\text { Dependent } \\
\text { Variable }\end{array}$ & group & $\mathrm{N}$ & M & SD & Adjusted $\mathrm{R}^{2}$ & $F(1)$ & $\mathrm{p}$ & partial $\eta^{2}$ \\
\hline \multirow{2}{*}{$\begin{array}{l}\text { Material } \\
\text { well-being }\end{array}$} & ID & 39 & 10,18 & 1.59 & \multirow{2}{*}{0.006} & \multirow{2}{*}{1.482} & \multirow{2}{*}{0.227} & \multirow{2}{*}{0.019} \\
\hline & TD & 40 & 9.75 & 1.55 & & & & \\
\hline \multirow{2}{*}{ Health } & ID & 39 & 12.44 & 1.60 & \multirow{2}{*}{0.145} & \multirow{2}{*}{14.186} & \multirow{2}{*}{0.000} & \multirow{2}{*}{0.156} \\
\hline & TD & 40 & 13.75 & 1.50 & & & & \\
\hline \multirow{2}{*}{ Productivity } & ID & 39 & 6.82 & 1.55 & \multirow{2}{*}{0.625} & \multirow{2}{*}{130.990} & \multirow{2}{*}{0.000} & \multirow{2}{*}{0.630} \\
\hline & TD & 40 & 11.55 & 2.07 & & & & \\
\hline \multirow{2}{*}{ Intimacy } & ID & 39 & 11.08 & 2.14 & \multirow{2}{*}{0.076} & \multirow{2}{*}{7.430} & \multirow{2}{*}{0.008} & \multirow{2}{*}{0.088} \\
\hline & TD & 40 & 12.23 & 1.56 & & & & \\
\hline \multirow{2}{*}{ Safety } & ID & 39 & 12.28 & 1.79 & \multirow{2}{*}{-0.013} & \multirow{2}{*}{0.027} & \multirow{2}{*}{0.870} & \multirow{2}{*}{0.000} \\
\hline & TD & 40 & 12.23 & 1.27 & & & & \\
\hline \multirow{2}{*}{$\begin{array}{l}\text { Place in } \\
\text { community }\end{array}$} & ID & 39 & 9.23 & 2.78 & \multirow{2}{*}{-0.006} & \multirow{2}{*}{0.564} & \multirow{2}{*}{0.455} & \multirow{2}{*}{0.007} \\
\hline & TD & 40 & 9.65 & 2.15 & & & & \\
\hline \multirow{2}{*}{$\begin{array}{l}\text { Emotional } \\
\text { well-being }\end{array}$} & ID & 39 & 10.56 & 2.14 & \multirow{2}{*}{0.012} & \multirow{2}{*}{1.950} & \multirow{2}{*}{0.167} & \multirow{2}{*}{0.025} \\
\hline & TD & 40 & 9.98 & 1.58 & & & & \\
\hline \multirow{2}{*}{ QoL total score } & ID & 39 & 72.59 & 7.70 & 0.190 & & & \\
\hline & TD & 40 & 79.13 & 5.32 & & & & \\
\hline
\end{tabular}

${ }^{* *} \mathrm{p}<0.01$

ID - intellectual disability; TD - typical development; QoL - Quality of Life; Statistically significant values are marked (bold).

No statistically significant differences were determined in any of the seven domains in objective indicators of QoL with regard to participants' gender ( $\mathrm{p}>0.05)$.

When analyzing the level of objective QoL in men with ID $(M=72.17, S D=7.45)$ and $T D$ men $(M=79.25, S D=4.98)$ significant differences were determined in QoL total score. TD men achieved significantly better results $(\mathrm{t}(36)=-3.478$, $\mathrm{p}=0.001)$.

Statistically significant differences were also determined in Health and Productivity domains. TD men ( $M=14.00$, $\mathrm{SD}=1.62$ ) were significantly healthier compared to men with ID 
Specijalna edukacija i rehabilitacija (Beograd), Vol. 17, br. 3. 305-334, 2018.

$(\mathrm{M}=12.72, \mathrm{SD}=1.64)(\mathrm{t}(36)=-2.413, \mathrm{p}=0.021)$. Furthermore, $\mathrm{TD}$ men $(\mathrm{M}=11.35, \mathrm{SD}=2.23)$ were significantly more productive compared to men with ID $(\mathrm{M}=6.61, \mathrm{SD}=1.61)(\mathrm{t}(36)=-7.428$, $\mathrm{p}=0.000)$.

Women with ID $(\mathrm{M}=73.05, \quad \mathrm{SD}=8.28)$ achieved significantly lower scores than $\mathrm{TD}$ women $(\mathrm{M}=79.00, \mathrm{SD}=5.76)$ $(\mathrm{t}(38)=-2.638, \mathrm{p}=0.012)$ on QoL total score. Women with ID $(\mathrm{M}=12.25, \mathrm{SD}=1.59)$ had more health problems compared to $\mathrm{TD}$ women $(\mathrm{M}=13.50, \mathrm{SD}=1.36)(\mathrm{t}(38)=-2.679, \mathrm{p}=0.011)$. Female participants with ID $(\mathrm{M}=6.90, \mathrm{SD}=1.48)$ were less productive than $\mathrm{TD}$ female participants $(\mathrm{M}=11.75, \mathrm{SD}=1.94)$ $(\mathrm{t}(38)=-8.872, \mathrm{p}=0.000)$. Women with ID $(\mathrm{M}=11.15, \mathrm{SD}=2.30)$ had a significantly lower score in Intimacy domain compared to $\mathrm{TD}$ women $(\mathrm{M}=12.55, \mathrm{SD}=1.43)(\mathrm{t}(31.80)=-2.311, \mathrm{p}=0.027)$.

Statistically significant correlations among the seven domains of QoL objective indicators in persons with ID were positive, ranging from moderate to high (Pallant, 2013). The lowest significant correlations were determined between Safety and QoL total score $(\mathrm{r}=0.330, \mathrm{p}<0.05)$, and the highest between Place in community and QoL total score $(\mathrm{r}=0.760, \mathrm{p}<0.01)$. Health was the only domain which did not significantly correlate with QoL total score, nor any of the remaining six domains of QoL objective indicators (Table 3).

Table 4 - Correlations among objective indicators of QoL in persons with ID

\begin{tabular}{|c|c|c|c|c|c|c|c|c|}
\hline & 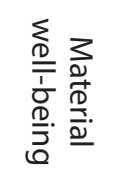 & $\begin{array}{l}\frac{I}{D} \\
\frac{\mathbb{D}}{F}\end{array}$ & 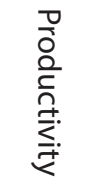 & 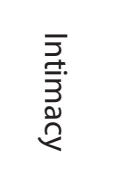 & 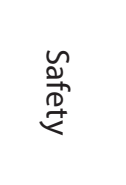 & 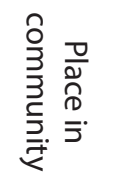 & 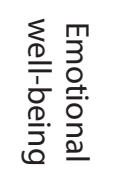 & 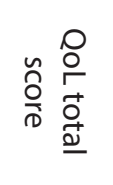 \\
\hline Material & - & -0.125 & 0.067 & 0.305 & 0.306 & 0.295 & $0.419^{* *}$ & $0.572^{* *}$ \\
\hline Health & -0.125 & - & -0.095 & -0.309 & 0.020 & -0.248 & -0.043 & -0.019 \\
\hline Productivity & 0.067 & -0.095 & - & 0.060 & -0.189 & $0.394^{*}$ & 0.071 & $0.330^{*}$ \\
\hline Intimacy & 0.305 & -0.309 & 0.060 & - & $0.508^{* *}$ & $0.368^{*}$ & $0.386^{*}$ & $0.647^{* *}$ \\
\hline Safety & 0.306 & 0.020 & -0.189 & $0.508^{* *}$ & - & $0.357^{*}$ & $0.500^{* *}$ & $0.670^{* *}$ \\
\hline Place in comm & 0.295 & -0.248 & $0.394^{*}$ & $0.368^{*}$ & $0.357^{*}$ & - & $0.452^{* *}$ & $0.760^{* *}$ \\
\hline $\begin{array}{l}\text { Emotional well- } \\
\text { being }\end{array}$ & $0.419^{* *}$ & -0.043 & 0.071 & $0.386^{*}$ & $0.500^{* *}$ & $0.452^{* *}$ & - & $0.756^{* *}$ \\
\hline QoL total score & $0.572^{* *}$ & -0.019 & $0.330^{*}$ & $0.647^{* *}$ & $0.670^{* *}$ & $0.760^{* *}$ & $0.756^{* *}$ & \\
\hline
\end{tabular}

${ }^{*} p=0.05$ level ${ }^{* *} p=0.01$ Statistically significant values are marked (bold). 


\section{DISCUSSION}

According to general results obtained in this research, a statistically significant difference was determined in QoL total score, as well as in certain domains (Health, Productivity and Intimacy) between experimental and control groups of participants (Table 2). Although the obtained result was expected, results of other studies in this field are not consistent, which especially refers to data on differences among selected life domains.

Hensel et al. (2002) determined that, according to scores obtained on Comprehensive Quality of Life Scale, TD persons had higher average values compared to participants with ID in the following domains: Health, Productivity, Place in community and Emotional well-being. The same tendency of results which indicate better QoL in TD persons compared to persons with ID, was also confirmed in a study which included more than a thousand persons ( $\mathrm{N}=1264)$ with mild and moderate ID, aged between 18 and 66 (Simões \& Santos, 2016). Scores indicating better QoL in TD participants were determined in both QoL total score and scores of six life domains (Personal development, Self-determination, Interpersonal relations, Social inclusion, Rights, Material well-being). Similar results were obtained in a somewhat older comparative study (Verri et al., 1999), which included adults with ID and TD persons from different geographical areas (Australia and Italy). The authors determined that persons with ID in Australia and Italy had lower QoL than TD participants in those countries only in the following life domains: Material well-being, Health, Productivity and Place in community. Also, there was no significant difference between Australian and Italian participants with ID in QoL total score, nor in selected life domains. Only slight advantages of one of the two groups were detected in some domains. Authors of an Iranian study (Hematian, Alborzi \& Khayyer, 2009), reported somewhat different results according to which persons with ID had the same QoL level as their TD 
peers with regard to QoL total score, while differences were determined only in the following domains: Life satisfaction, Competency/productivity and Social belongingness/community integration in favor of persons with ID. TD participants had better QoL in Empowerment/independence domain.

According to the results of above mentioned studies, it seems that contribution of different domains to the overall QoL level is uneven, which leads to differences in QoL total score values, thus raising new research questions.

According to average score values in Health domain (frequency of visits to doctors, comorbid medical conditions, and taking medications) in this research, persons with ID had significantly lower QoL, i.e. more health problems. The obtained finding was expected, since according to the literature, $73 \%$ of people with ID needed additional medical interventions (Webb \& Rogers, 1999), while mental disorders were detected in $46 \%$ of people with ID, as opposed to TD persons in whom these disorders appeared in 36\% of cases (Vanny, Levy, Greenberg \& Hayes, 2009). On the other hand, about $90 \%$ of medical staff stated that they had difficulties in treating people with ID and mentioned the following key barriers: difficulties in assessment, communication limitations, limitations in consultation time and insufficient knowledge about the ID phenomenon (Cook \& Lennox, 2000). In our environment, parents of people with ID stated the following factors as the most significant for better health care of their children: additional time for medical examination, good communication with doctors and their readiness to intervene in order to alleviate other problems their children have in addition to ID (Dučić, Kaljača \& Pašćan, 2016). It is evident that higher risk and prevalence of different types of illnesses, as well as limited availability of adequate medical treatment significantly influence the increased vulnerability of health and general QoL of people with ID.

Statistically significant differences in Productivity and Intimacy domains determined in this research between participants with ID and TD participants, and in favor of TD 
participants, can be considered expected. Lower average score of ID group compared to the control group in Productivity domain (the indicators referred to the time spent at work or in other formal activities, the quality and structure of leisure time) indicated that TD participants were more likely to be employed, and thus spent more time on professional training, taking care of their family, and had less free time for activities such as watching TV. Bouck (2012) indicates that education of persons with ID who attended special education curriculum in transition period did not have a significant influence on their QoL after finishing school. Most of these students (97\%) did not live independently, nor continued their education or training in any way (93.4\%), and more than a half (56.6\%) never had a paid job after finishing secondary school. Even if they did have a paid job, most of them did not work full time and had relatively low wages. Work experience that people with ID gain in secondary school and their parents' expectations regarding their employment are considered the most important predictors of successful and competitive employment of adults with ID (Wehman et al., 2015). However, the influence of such experience on later employment is limited. It seems that even when students with ID have a more positive experience in practical training compared to their TD peers, as well as greater commitment to work (Milanović-Dobrota \& RadićŠestić, 2017), a positive effect regarding the employment perspective is absent in our environment. It is possible that some other predictors are more important, such as the deficit in self-determined behavior skills in making professional decisions in transition period (Radić-Šestić, MilanovićDobrota \& Radovanović, 2015), deficits in social skills and communication in a working environment, as well as limited professional interests (Gligorović \& Matić, 2017), but also the predominantly negative attitudes of employers toward hiring people with ID, and unfavorable laws (Kaljača, Žunić-Pavlović \& Dučić, 2011). With regard to the quality of leisure time of people with ID, it appears that accepted patterns of behavior which reflect the tendency of children and youth with ID to 
participate mainly in household, isolated, and stereotyped activities in their leisure time (Kaljača, Dučić \& Cvijetić, 2018), tend to persist in adulthood.

Intimacy domain in this research was determined by indicators which evaluated socio-emotional relationship between the participants and other people. Lower average scores and significantly lower level of QoL of persons with ID in this domain is in accordance with the results of previous studies which indicate limitations in social skills, social participation (Baurain \& Nader-Grosbois, 2013; King, Shields, Imms, Black \& Ardern, 2013; Solish, Perry \& Minnes, 2010) number of friends (Kaljača et al., 2018; Tipton, Christensen \& Blacher, 2013), communication (Belva, Matson, Sipes \& Bamburg, 2012), as well as more frequent behavioral problems (Lundqvist, 2013), which all together have a negative effect on establishing and maintaining desirable socio-emotional relations and QoL.

In this research the relation between gender and $\mathrm{QoL}$ total score was statistically significant in both male and female groups of participants. In both groups, participants with ID had statistically lower average total scores than TD participants. Significant differences were also determined in the included domains. TD men had a higher average value of indicators in Health and Productivity domains, while TD women had fewer health problems, they were more productive and had better socio-emotional relations with their environment. Poorer health status of persons with ID can be related to findings of other authors, according to which these persons have a significantly lower quality of preventive health care than TD persons, even when the frequency of visiting doctors is equal in both groups. The authors believe that this can be the result of insufficient initiative of persons with ID to undergo different screening procedures, as well as of doctors' attitudes toward including these patients in the mentioned procedures (Whitfield, Langan \& Russell, 1996). Furthermore, no statistically significant differences in health quality were determined between the participants of different genders 
within the population with ID (Basgul, Uneri \& Cakin-Memik, 2011). Differences in the productivity domain are probably the result of significantly smaller number of employed persons with ID compared to their TD peers (Bouck, 2012). Apart from the mentioned two domains, differences between women with ID and TD women were also present in Intimacy domain, which was not determined between men from these two groups. This is possibly the result of significantly richer social life of TD women compared to TD men, and greater participation in social activities (women have significantly more close friends and contacts with their neighbors). These gender differences were not determined in the group with ID (Umb-Carlsson \& Sonnander, 2006).

The obtained results lead to the conclusion that general QoL of persons with ID of both genders is in our environment endangered by the combined influence of similar unfavorable personal factors (lower health status) on one hand, and social factors on the other hand (limitations in employment and socioemotional closeness with the environment), which represents a challenge for greater engagement of different forms of profiled community support.

\section{Correlations}

Emotional well-being domain represents the freedom of choice and accomplishment level of personal desires. In the sample of persons with ID, Emotional well-being significantly, positively and moderately correlated with Material well-being. Although research conducted in Serbia determined that material and financial capabilities of families of persons with ID did not have a significant influence on the level and frequency of their participation in social, fun, and recreational activities (Kaljača, Cvijetić \& Dučić, 2014), it is well known that persons with ID are often faced with the lack of material goods (Emerson, 2004; Emerson \& Hatton, 2007). Therefore, the results of this research are interpreted by engaging support services for 
socially vulnerable groups which partly neutralize the negative influence of poverty of ID persons' parents (Kaljača, Cvijetić \& Dučić, 2014). More recent studies determined that regardless of engaging support services, persons with ID participated in mentioned leisure activities significantly less than TD persons (Kaljača, Dučić \& Cvijetić, 2018). Transportation costs were given as one of the possible causes of limited participation of persons with ID in activities such as: socializing with friends, going to a store or church (Abbott \& McConkey, 2006). The correlation between emotional and material well-being leads to the conclusion that lack of financial resources can also be the cause of unfulfilled wishes and limited choice of activities of persons with ID.

A statistically significant and positive correlation was determined between Emotional well-being domain and Intimacy domain which represents the quality of social relations. When persons with ID were expected to say what their greatest wish was, priority was given to wishes for social acceptance, popularity, i.e. positive social status, and good relationships with family members (Dykens, Schwenk, Maxwell \& Myatt, 2007). The result obtained in this research confirmed that the level of achievement of wishes for good social relations positively correlated with emotional well-being in persons with ID.

Emotional well-being domain had a statistically significant and positive correlation with Safety domain, which refers to the level of anxiety in persons with ID, and with Place in community domain, which represents the social status of persons with ID. People with disabilities face various challenges in attempting to participate in activities of their social community. One of the barriers they frequently encounter is the lack of experience in social interactions and fear from being rejected by TD persons who are the majority of general population. Becoming a member of a sports club or going to a restaurant alone for the first time are significant sources of anxiety for persons with disabilities. However, if their initial experience is positive, their motivation to participate in community activities will grow. By being more and more accepted by TD persons, the quality of 
achieved social relations, i.e. the social status of persons with ID improves, and their anxiety level decreases (Milner \& Kelly, 2009). The relation between social status and the quality of social relations was also determined by statistically significant, positive correlations between Place in community and Intimacy domains.

People with disability feel safer in an environment in which they are accepted and where their opinion is appreciated (Milner \& Kelly, 2009), which was confirmed by correlations between Place in community and Safety domains.

There was a statistically significant and positive correlation between Place in community of people with ID and their Productivity. Certain authors use the acquisition level of independent living skills and the level of productivity as indicators of the level of social inclusion (Cobigo, OuelletteKuntz, Lysaght \& Martin, 2012). Persons with ID state that TD persons often have negative attitudes towards their participation in community activities, and that their rights are not sufficiently respected within the community. They feel that their family members and people who support them do not perceive them as adults, and that they do not have enough opportunities for work placement (Abbott \& McConkey, 2006). By allowing persons with ID to take on part of responsibility for tasks at work or within organized groups such as citizens' associations, sports clubs, or art colonies, they are given a chance to increase their productivity and contribute to the community they live in.

Safety domain significantly, positively, and moderately correlated with Intimacy domain. The obtained results are in accordance with findings of other authors. A significantly higher level of anxiety was determined in persons with ID than in TD persons (Emerson, 2003). The tendency is that general level of anxiety, as well as frequency of social phobia in this population increases with age. A higher level of anxiety represents a higher risk of externalizing behavior problems in persons with ID than in TD persons (Green, Berkovits \& 
Specijalna edukacija i rehabilitacija (Beograd), Vol. 17, br. 3. 305-334, 2018.

Baker, 2015). Persons with ID who have no sleeping problems, who feel safe in their homes and are less anxious, have fewer risks of expressing socially undesirable forms of behavior and are more successful in social relations.

This research determined that Health was the only domain which did not correlate significantly with any of the remaining six domains, nor with QoL total score. This result was completely unexpected and contrary to the results of other studies mentioned above. Perhaps this result can be related to the finding according to which the presence of psychological distress has a greater predictive value for QoL total score in persons with milder forms of ID than health-related QoL (Endermann, 2013). However, Health indicators in this Scale do not measure any of the psychological well-being aspects (emotional competence, exposure to stress, reactions to stress, etc.).

\section{CONCLUSION}

Differences in objective QoL indicators were determined in this research between adults with ID and their TD peers.

By applying the Multivariate analysis of variance (MANOVA), we obtained the results which indicate the presence of a statistically significant difference $(\mathrm{p}=0.000)$ in QoL total score between participants with ID and TD participants. On average, TD participants had significantly better objective overall QoL score than participants with ID.

By applying the same statistical method (MANOVA), it was determined that, according to average scores, TD participants were significantly better than participants with ID in three included QoL domains: Health $(\mathrm{p}=0.000)$, Productivity $(\mathrm{p}=0.000)$ and Intimacy $(\mathrm{p}=0.008)$.

The relation among gender, QoL total score, and some individual QoL domains was statistically significant. TD men had significantly better $(\mathrm{p}=0.001)$ QoL total score than men with ID, and the same tendency was present in TD women 
compared to women with ID ( $\mathrm{p}=0.012)$. Differences with regard to gender between the two compared groups of participants were also determined in some of the included QoL domains. According to the applied indicators, TD men were significantly healthier than men with ID ( $\mathrm{p}=0.021)$ and significantly more productive $(\mathrm{p}=0.000)$. Women with ID had significantly more health problems than TD women $(\mathrm{p}=0.011)$, a significantly lower level of productivity $(\mathrm{p} \leq 0.000)$, as well as significantly lower average scores in Intimacy domain ( $\mathrm{p}=0.027)$.

Pearson correlation coefficient was used to determine the significance and correlation level of dependent variables. In participants with ID, the presence of statistically significant correlations among most of the included domains was determined, as well as their significant relation with QoL total score (Table 3$)$. The obtained correlations were positive, ranging from moderate $(\mathrm{r}=0.330, \mathrm{p}<0.05)$ to high $(\mathrm{r}=0.760$, $\mathrm{p}<0.01)$. The only exception was determined in Health domain, which did not significantly correlate with QoL total score, nor any of the remaining six domains of objective QoL indicators.

The presented results lead to the conclusion that there is a significant level of QoL deprivation in people with ID according to objective indicators, both in general quality and in individual life domains. According to this research, limitations and barriers in health care, employment opportunities, and socio-emotional relations with the environment, are singled out as areas in which people with ID are at a particular disadvantage. Thus, practical implications of these results should refer to the improvement of different forms of formal and informal support [creating support programs which would be applied in the family environment, as well as in the community (day care centers, small home communities), and which would be directed at improving social skills, especially communicative abilities of adults with ID, as well as self-determination skills; creating training programs for medical staff so that they become more familiar with the ID phenomenon and ways of communicating with patients with ID; legislation amendments which would enable the employment of a larger number of adults with ID]. Society should provide a 
more favorable environment that would, to the greatest possible extent, reduce all forms of discrimination against people with developmental disabilities, in order to balance the preconditions important for QoL of all persons in a community, regardless of individual differences.

The determined differences in selected domains imply that greater engagement of support services is required in those areas, as well as other factors (organized services and a wider range of profiled formal support activities aimed at people with ID and their families, changes in attitudes of TD population, as well as changes of laws in different areas of human rights).

\section{REFERENCES}

1. Abbott, S., \& McConkey, R. (2006). The barriers to social inclusion as perceived by people with intellectual disabilities. Journal of Intellectual Disabilities, 10(3), 275-287. doi:10.1177/1744629506067618

2. Albrecht, G. L., \& Devlieger, P. J. (1999). The disability paradox: High quality of life against all odds. Social Science \& Medicine, 48(8), 977-988. doi:10.1016/s0277-9536(98)00411-0

3. Barcaccia, B., Esposito, G., Matarese, M., Bertolaso, M., Elvira, M., \& De Marinis, M. G. (2013). Defining quality of life: A wild-goose chase? Europe's Journal of Psychology, 9(1), 185-203. doi:10.5964/ ejop.v9i1.484

4. Başgül, Ş. S., Üneri, Öz. Ş., \& Çakın-Memik, N. (2011). Parents' perception of the quality of life of children with intellectual disabilities. The Turkish Journal of Pediatrics, 53(5), 541-546.

5. Baurain, C., \& Nader-Grosbois, N. (2013). Theory of mind, socio-emotional problem-solving, socio-emotional regulation in children with intellectual disability and in typically developing children. Journal of Autism Developmental Disorders, 43(5), 10801097. doi:10.1007/s10803-012-1651-4

6. Belva, B. C., Matson, J. L., Sipes, M., \& Bamburg, J. W. (2012). An examination of specific communication deficits in adults with profound intellectual disabilities. Research in Developmental Disabilities, 33(2), 525-529. doi:10.1016/j.ridd.2011.10.019 
7. Bouck, E.C. (2012). Secondary students with moderate/severe intellectual disability: Considerations of curriculum and postschool outcomes from the National Longitudinal Transition Study. Journal of Intellectual Disability Research, 56(12), 11751186. doi:10.1111/j.1365-2788.2011.01517.x

8. Buntinx, W. H. E., \& Schalock, R. L. (2010). Models of disability, quality of life, and individualized supports: Implications for professional practice in intellectual disability. Journal of Policy and Practice in Intellectual Disabilities, 7(4), 283-294. doi:10.1111/ j.1741-1130.2010.00278.x

9. Cho, E., \& Kim, S. (2015). Cronbach's coefficient alpha: Well known but poorly understood. Organizational Research Methods, 18(2), 207-230. doi:10.1177/1094428114555994

10. Chou, Y. C., Schalock, R. L., Tzou, P. Y., Lin, L. C., Chang, A. L., Lee, W. P., \& Chang, S. C. (2007). Quality of life of adults with intellectual disabilities who live with families in Taiwan. Journal of Intellectual Disability Research, 51(11), 875-883. doi:10.1111/ j.1365-2788.2007.00958.x

11. Cobigo, V., Ouellette-Kuntz, H., Lysaght, R., \& Martin, L. (2012). Shifting our conceptualization of social inclusion. Stigma Research and Action, 2(2), 75-84. doi: 10.5463/SRA.vli1.10

12. Cook, A., \& Lennox, N. (2000). General practice registrars' care of people with intellectual disabilities. Journal of Intellectual \& DevelopmentalDisability,25(1), 69-77. doi:10.1080/132697800112794

13. Cramm, J. M., \& Nieboer, A. P. (2012). Longitudinal study of parents' impact on quality of life of children and young adults with intellectual disabilities. Journal of Applied Research in Intellectual Disabilities, 25(1), 20-28. doi:10.1111/j.1468-3148.2011.00640.x

14. Cummins, R. A. (1997). Comprehensive quality of life scale, intellectual disability, 5th edition-manual. Melbourne: School of Psychology, Deakin University.

15. Cummins, R. A. (1998). Quality oflife. definition and terminology; a discussion document from the international society of quality of life studies. Melbourne: Deaking University - School of Psychology.

16. Cummins, R. A. (2001). Self-rated quality of life scales for people with an intellectual disability: A reply to Ager \& Hatton. Journal of Applied Research in Intellectual Disabilities, 14(1), 1-11. doi:10.1046/j.1360-2322.2001.00057.x 
Specijalna edukacija i rehabilitacija (Beograd), Vol. 17, br. 3. 305-334, 2018.

17. Cummins, R. A., McCabe, M. P., Romeo, Y., Reid, S., \& Waters, L. (1997). An initial evaluation of the Comprehensive quality of life scale - intellectual disability. International Journal of Disability, 44(1), 7-19. doi.org/10.1080/0156655970440102

18. Dučić, B., Kaljača, S., \& Pašćan, D. (2016). Health care quality for persons with intellectual disabilities. In S. Nikolić, R. Nikić, V. Ilanković (Eds), IV International Scientific Conference "Special Education and Rehabilitation - Early Intervention" (pp. 599614), 14-16 October, Subotica: University of Belgrade - Faculty of Special Education and Rehabilitation, Serbia.

19. Dykens, E., Schwenk, K., Maxwell, M., \& Myatt, B. (2007). The sentence completion and three wishes tasks: Windows into the inner lives of people with intellectual disabilities. Journal of Intellectual Disability Research, 51(8), 588-597. doi:10.1111/j.13652788.2006.00937.x

20. Emerson, E. (2003). Prevalence of psychiatric disorders in children and adolescents with and without intellectual disability. Journal of Intellectual Disability Research, 47(1), 51-58. doi:10.1046/j.13652788.2003.00464.x

21. Emerson, E. (2004). Poverty and children with intellectual disabilities in the world's richer countries. Journal of Intellectual and Developmental Disability, 29(4), 319-338. doi:10.1080/13668250400014491

22. Emerson, E., \& Hatton, C. (2007). Mental health of children and adolescents with intellectual disabilities in Britain. The British Journal of Psychiatry, 191(6), 493-499. doi:10.1192/bjp. bp.107.038729

23. Endermann, M. (2013). Predictors of health-related and global quality of life among young adults with difficult-to-treat epilepsy and mild intellectual disability. Epilepsy \& Behavior, 26(2), 188195. doi:10.1016/j.yebeh.2012.12.002

24. Fellinghauer, B., Reinhardt, J.D., Stucki, G., \& Bickenbach, J. (2012). Explaining the disability paradox: A cross-sectional analysis of the Swiss general population. BMC Public Health, 12(1), 655-664. doi:10.1186/1471-2458-12-655

25. Garson, G. D. (2012). Testing statistical assumptions. Asheboro, NC: Statistical Associates Publishing. 
26. Gligorović, M., \& Matić, K. (2017). Ponašanje u radnom okruženju adolescenata sa teškoćama u mentalnom razvoju. Specijalna edukacija i rehabilitacija, 16(4), 425-443. doi:10.5937/ specedreh16-14437

27. Green, S. A., Berkovits, L. D., \& Baker, B. L. (2015). Symptoms and development of anxiety in children with or without intellectual disability. Journal of Clinical Child \& Adolescent Psychology, 44(1), 137-144. doi:10.1080/15374416.2013.873979

28. Hematian, K., Alborzi, S., \& Khayyer, M. (2009). Quality of the life of Iranian vocational students with and without intellectual disability. Psyhological Reports, 105(3), 738-746. doi:10.2466/ pr0.105.3.738-746

29. Hensel, E. (2000). A comparison of quality of and satisfaction with life between people with an intellectual disability and those without. Thesis submitted for the degree of Doctorate in Clinical Psychology. University of Birmingham: School of Psychology. Retrieved May 20, 2018, from: http://etheses.bham.ac.uk/515/1/ Hensel00ClinPsyD.pdf

30. Hensel, E., Rose, J., Stenfert Kroese, B., \& Banks-Smith, J. (2002). Subjective judgements of quality of life: A comparison study between people with intellectual disability and those without disability. Journal of Intellectual Disability Research, 46(2), 95-107. doi:10.1046/j.1365-2788.2002.00343.x

31. Ilić, I., Milić, I., \& Aranđelović, M. (2010). Procena kvaliteta života - sadašnji pristupi. Acta Medica Medianae, 49(4), 52-60.

32. Jenaro, C., Verdugo, C. M. A., Caballo, C., Balboni, G., Lachapelle, Y., Otrebski, W., \& Schalock R. L. (2005). Cross-cultural study of person-centred quality of life domains and indicators: A replication. Journal of Intellectual Disability Research, 49(10), 734739. doi:10.1111/j.1365-2788.2005.00742.x

33. Jonsson, U., Alaie, I., Wilteus, A.L., Zander, E., Marschik, P. B., David Coghill, D., \& Bölte, S. (2016). Annual research review: Quality of life and childhood mental and behavioural disorders - a critical review of the research. Journal of Child Psychology and Psychiatry, 58(4), 439-469. doi:10.1111/jcpp.12645

34. Julius, E., Wolfson, H., \& Yalon-Chamovitz, S. (2003). Equally unequal: Gender discrimination in the workplace among adults 
Specijalna edukacija i rehabilitacija (Beograd), Vol. 17, br. 3. 305-334, 2018.

with mental retardation. WORK: A Journal of Prevention, Assessment \& Rehabilitation, 20(3), 205-213.

35. Kaljača, S., Cvijetić, M., \& Dučić, B. (2014). Participacija osoba sa intelektualnom ometenošću u rekreativnim i socijalnim aktivnostima. Specijalna edukacija i rehabilitacija, 13(2), 173-193. doi:10.5937/specedreh13-6495

36. Kaljača S., Dučić, B., \& Cvijetić, M. (2018). Participation of children and youth with neurodevelopmental disorders in afterschool activities. Disability and Rehabilitation doi:10.1080/09638 288.2018.1457092

37. Kaljača, S., Žunić-Pavlović, V., \& Dučić, B. (2011). Unapređenje procesa zapošljavanja osoba sa intelektualnom ometenošću. U M. Vantić-Tanjić (ur.), Unapređenje kvalitete života djece i mladih, II međunarodna naučno-stručna konferencija (str. 533-540). Tuzla: Udruženje za podršku i kreativni razvoj djece i mladih, $\mathrm{BiH}, 11$ 12. 06. 2011.

38. King, M., Shields, N., Imms, C., Black, M., \& Ardern, C. (2013). Participation of children with intellectual disability compared with typically developing children. Developmental Disabilities, 34(5), 1854-1862. doi:10.1016/j.ridd.2013.02.029

39. Lucas-Carrasco, R., \& Salvador-Carulla, L. (2012). Life satisfaction in persons with intellectual disabilities. Research in Developmental Disabilities, 33(4), 1103-1109. doi:10.1016/j.ridd.2012.02.002

40. Lundqvist, L. O. (2013). Prevalence and risk markers of behavior problems among adults with intellectual disabilities: A total population study in Örebro county, Sweden. Research in Developmental Disabilities, 34(4), 1346-1356. doi:10.1016/j. ridd.2013.01.010

41. Milanović-Dobrota, B., \& Radić-Šestić, M. (2017). Rana angažovanost srednjoškolaca na praktičnoj nastavi. Nastava $i$ vaspitanje, 66(1), 67-82. doi:10.5937/nasvas1701067m

42. Milner, P., \& Kelly, B. (2009). Community participation and inclusion: People with disabilities defining their place. Disability \& Society, 24(1), 47-62. doi:10.1080/09687590802535410

43. Nota, L., Ferrari, L., Soresi, S., \& Wehmeyer, M. (2007). Selfdetermination, social abilities and the quality of life of people with intellectual disability. Journal of Intellectual Disability Research, 51(11), 850-865. doi:10.1111/j.1365-2788.2006.00939.x 
44. Nota, L., Soresi, S., \& Perry, J. (2006). Quality of life in adults with an intellectual disability: The evaluation of quality of life instrument. Journal of Intellectual Disability Research, 50(5), 371385. doi:10.1111/j.1365-2788.2006.00785.x

45. Pallant, J. (2013). SPSS survival manual. McGraw-Hill Education (UK).

46. Perry, J., \& Felce, D. (2002). Subjective and objective quality of life assessment: Responsiveness, response bias, and resident: Proxy concordance. Mental Retardation, 40(6), 445-456. doi:10.1352/0047-6765(2002)040<0445:saoqol >2.0.co;2

47. Petry, K., Maesa, B., \& Vlaskamp, C. (2009). Measuring the quality of life of people with profound multiple disabilities using the QOL-PMD: First results. Research in Developmental Disabilities, 30(6), 1394-1405. doi:10.1016/j.ridd.2009.06.007

48. Radić-Šestić, M., Milanović-Dobrota, B., \& Radovanović, V. (2015). Poteškoće u donošenju profesionalni odluka učenika sa lakom intelektualnom ometenošću i tipičnih vršnjaka. Specijalna edukacija i rehabilitacija, 14(3), 383-407. doi:10.5937/ specedreh14-9182

49. Ribeiro, J., Silva, T., Varela, C., Gonçalves, I., Rodrigo, A., Gomes, F., \& Santos, S. (2017). Quality of life of people with DID with significant support needs: A comparative study with non-DID pairs. Research and Networks in Health, 3(1), 1-11.

50. Ruddick, L. (2005). Health of people with intellectual disabilities: A review of factors influencing access to health care. British Journal of Health Psychology, 10(4), 559-570. doi:10.1348/135910705x43769

51. Ruta, D., Camfield, L., \& Donaldson, C. (2007). Sen and the art of quality of life maintenance: Towards a general theory of quality of life and its causation. Journal of Socio-Economics, 36(3), 397-423. doi:10.1016/j.socec.2006.12.004

52. Schalock, R. L., Brown, I., Brown, R., Cummins, R. A., Felce, D., Mattika, L., ... Parmenter, T. (2002). Conceptualization, measurement, and application of quality of life for persons with intellectual disabilities: Report of an international panel of experts. Mental Retardation, 40(6), 457-470. doi:10.1352/00476765(2002)040<0457:cmaaoq $>2.0 . c 0 ; 2$ 
Specijalna edukacija i rehabilitacija (Beograd), Vol. 17, br. 3. 305-334, 2018.

53. Schalock, R. L. (2004). The concept of quality of life: What we know and do not know. Journal of Intellectual Disability Research, 48(3), 203-216. doi:10.1111/j.1365-2788.2003.00558.x

54. Schalock, R. L., Verdugo, M. A., Jenaro, C., Wang, M., Wehmeyer, M., Jiancheng, X., Lachapelle, Y. (2005). Cross-cultural study of quality of life indicators. American Journal on Mental Retardation, 110(4), 298-331. doi:10.1352/0895-8017(2005)110[298:csoqol]2.0. со; 2

55. Sheppard-Jones, K. (2003). Quality of life dimensions for adults with developmental disabilities. Doctoral Dissertations. USA: University of Kentucky. Retrieved Jun 15, 2018, from: https:// uknowledge.uky.edu/cgi/viewcontent.cgi?referer=https://www. google.rs/\&httpsredir=1\&article=1338\&context=gradschool_diss

56. Simões, C., \& Santos, S. (2016). Comparing the quality of life of adults with and without intellectual disability. Journal of Intellectual Disability Research, 60(4), 378-388. doi:10.1111/ jir.12256

57. Solish, A., Perry, A., \& Minnes, P. (2010). Participation of children with and without disabilities in social, recreational and leisure activities. Journal of Applied Research in Intellectual Disabilities, 23(3), 226-236. doi:10.1111/j.1468-3148.2009.00525.x

58. The WHOQOL Group (1995). The World Health Organization quality of life assessment (WHOQOL): Position paper from the World Health Organization. Social Science \& Medicine, 41(10), 1403-1409. doi:10.1016/0277-9536(95)00112-k

59. Tipton, L., Christensen, L., \& Blacher, J. (2013). Friendship quality in adolescents with and without an intellectual disability. Journal of Applied Research in Intellectual Disabilities, 26(6), 522- 532. doi:10.1111/jar.12051

60. Townsend-White, C., Pham, A. N. T., \& Vassos, M. V. (2012). A systematic review of quality of life measures for people with intellectual disabilities and challenging behaviours. Journal of Intellectual Disability Research, 56(3), 270-284. doi:10.1111/j.13652788.2011.01427.x

61. Umb-Carlsson, O., \& Sonnander, K. (2006). Living conditions of adults with intellectual disabilities from a gender perspective. Journal of Intellectual Disability Research, 50(5), 326-334. doi:10.1111/j.1365-2788.2005.00779.x 
62. van Asselt-Goverts, A. E., Embregts, P. J. C. M., \& Hendriks, A. H. C. (2015). Social networks of people with mild intellectual disabilities: Characteristics, satisfaction, wishes and quality of life. Journal of Intellectual Disability Research, 59(5), 450-461. doi:10.1111/jir.12143

63. Vanny, K. A., Levy, M. H., Greenberg, D. M., \& Hayes, S. C. (2009). Mental illness and intellectual disability in Magistrates Courts in New South Wales, Australia. Journal of Intellectual Disability Research, 53(3), 289-297. doi:10.1111/j.1365-2788.2008.01148.x

64. Verri, A., Cummins, R. A., Petito, F., Vallero, E., Monteath, S., Gerosa, E., \& Nappi, G. (1999). An Italian-Australian comparison of quality of life among people with intellectual disability living in the community. Journal of Intellectual Disability Research, 43(6), 513-522. doi:10.1046/j.1365-2788.1999.00241.x

65. Webb, O. J., \& Rogers, L. (1999). Health screening for people with intellectual disability: The New Zealand experience. Journal of Intellectual Disability Research, 43(6), 497-503. doi:10.1046/j.13652788.1999.00233.x

66. Wehman, P., Sima, A. P., Ketchum, J., West, M. D., Chan, F., \& Luecking, R. (2015). Predictors of successful transition from school to employment for youth with disabilities. Journal of Occupational Rehabilitation, 25(2), 323-334. doi:10.1007/s10926014-9541-6

67. Whitfield, M., Langan, J., \& Russell, O. (1996). Assessing general practitioners' care of adult patients with learning disability: Casecontrol study. Quality in Health Care, 5(1), 31-35.

68. Wilson, K. S., Wiersma, L. D., \& Rubin, D. A. (2016). Quality of life in children with Prader Willi syndrome: Parent and child reports. Research in Developmental Disabilities, 57(1), 149-157. doi:10.1016/j.ridd.2016.06.016

69. Wong, P. K. S., Wong, D. F. K., Schalock, R. L., \& Chou, Y-C. (2011). Initial validation of the Chinese quality of life questionnaire - intellectual disabilities (CQOL-ID): A cultural perspective. Journal of Intellectual Disability Research, 55(6), 572-580. doi:10.1111/j.1365-2788.2011.01412.x 


\title{
KVALITET ŽIVOTA ODRASLIH OSOBA SA INTELEKTUALNOM OMETENOŠĆU - OBJEKTIVNI INDIKATORI
}

\author{
Svetlana Kaljača*, Bojan Dučić*, Sara Đorđićc* \\ *Univerzitet u Beogradu - Fakultet za specijalnu edukaciju i rehabilitaciju \\ ${ }^{* *}$ Osnovna škola „Sava Jovanović Sirogojno“, Beograd, Srbija
}

\begin{abstract}
Rezime
Ciljevi ovog istraživanja su utvrđivanje nivoa objektivnog kvaliteta života (KŽ) odraslih osoba sa intelektualnom ometenošću (IO), razlika u $\mathrm{KŽ} \mathrm{u} \mathrm{odnosu} \mathrm{na} \mathrm{pol} \mathrm{ispitanika,} \mathrm{kao} \mathrm{i} \mathrm{odnosa} \mathrm{ispitanih} \mathrm{životnih} \mathrm{domena}$ koji su obuhvaćeni primenjenim konceptom KZ̆.

Uzorkom je obuhvaćeno 39 odraslih osoba sa lakom i umerenom IO, kalendarskog uzrasta od 22 do 50 godina $(\mathrm{M}=34,69, \mathrm{SD}=7,49)$, i 40 ispitanika tipičnog razvoja (TR), kalendarskog uzrasta od 19 do 60 godina $(\mathrm{M}=35,25, \mathrm{SD}=12,21)$.

Za procenu nivoa KŽ korišćeno je sedam domena Skale za procenu kvaliteta života osoba sa intelektualnom ometenošću: Materijalno blagostanje, Zdravlje, Produktivnost, Intimnost, Sigurnost, Mesto u zajednici i Emocionalno blagostanje koji predstavljaju indikatore objektivnog KŽ.

Ispitanci sa IO imali su značajno niži KŽ od ispitanika TR na ukupnom skoru $(\mathrm{p}=0,000)$ i na domenima $Z$ dravlje $(\mathrm{p}=0,000)$, Produktivnost $(\mathrm{p}=0,000)$ i Intima $(\mathrm{p}=0,008)$. Muškarci TR u poređenju sa muškarcima sa IO imali su viši ukupni skor $(\mathrm{p}=0,001)$, i bolje rezultate na domenima Zdravlje $(\mathrm{p}=0,021)$ i Produktivnost $(\mathrm{p}=0,000)$. Ovaj nalaz je potvrđen $\mathrm{i}$ kod ispitanica s tim što su u poređenju žena TR i žena sa IO, žene TR bile značajno uspešnije i u domenu Intima $(\mathrm{p}=0,027)$. Statistički značajne korelacije sedam domena objektivnih pokazatelja kvaliteta života kod osoba sa IO su pozitivne i kreću se u rasponu od umerenih do visokih.

Dobijeni rezultati upućuju na domene u kojima je potrebno intenziviranje podrške kako bi se osobama sa IO pružila mogućnost da ostvare KŽ koji odgovara normama zajednice kojoj pripadaju.

Ključne reči: kvalitet života, intelektualna ometenost, službe podrške, zdravlje, produktivnost, intimnost
\end{abstract}

Primljeno: 20.07.2018.

Prihvaćeno: 13.09.2018. 